КУЦЕНКО М. Ю., канд. техн. наук, доцент, ДУДІН О. А., канд. техн. наук, доцент, ПАХАР Г. В., магістр, ДАНИЛЕНКО О. М., магістр, ДУБИНА О. М., магістр (Український державний університет залізничного транспорту)

\title{
Задачі реконструкції плану залізничної колії та підходи до їх вирішення
}

Процес переходу до швидкісного руху супроводжується низкою проблем, головними з яких $\epsilon$ задачі переулаштування плану залізниць. У статті розглянуто основні задачі щзодо реконструкції плану залізничної колії та підходи до їх вирімення. Запропоновано розглядати реконструкцію складних дільниць плану для введення швидкісного руху як задачі покращення параметрів модулів, з яких складається ией план. Реконструкиію слід здійснювати усередині модуля, не виходячи за його межі, щзо дасть змогу зберегти існуюче положення плану.

Ключові слова: залізничний транспорт, залізнична колія, швидкісний рух, реконструкція залізниць.

\begin{tabular}{l}
\hline Постановка проблеми \\
\hline На сьогоднішній день, коли \\
залізничної галузі 3 іншими видами транспорту $є$ \\
великою, приділяється особлива увага якості \\
функціонування залізниці, особливо питанням \\
збільшення швидкостей руху поїздів і впровадження \\
ресурсозберігаючих технологій $[1,2]$. \\
Перехід до швидкісного руху пов'язаний з низкою \\
проблем, головними 3 яких є завдання перебудови \\
плану залізниць, і в першу чергу збільшення радіусів \\
кругових кривих до величин 1200 і більше метрів, \\
подовженням прямих вставок і перехідних кривих.
\end{tabular}

\footnotetext{
Аналіз останніх досліджень і публікацій

Вітчизняна і зарубіжна наука залізничної галузі приділяла достатню увагу цим питанням, але сьогодні життя висуває нові, більш жорсткі вимоги.

Історично склався ряд методів розрахунків при вирішенні задач реконструкції плану. Найбільш досконалий - метод нормалей [3], який через відомі труднощі застосовується обмежено.

Поширеними є наближені евольвентні методи, такі як:

- метод кутових діаграм;

- метод перебільшеного плану.

3 упровадженням обчислювальної техніки найбільшого поширення набули методи із застосуванням прямокутних координат, вільні від недоліків евольвентних методів.

Існують два класи завдань реконструкції плану:

- надання плану правильного геометричного обрису;
}

- реконструкція плану з метою поліпшення його характеристик (збільшення радіуса кругових кривих, збільшення довжин перехідних кривих, збільшення довжин прямих вставок між суміжними кривими).

Завдання реконструкції плану розглянуто в [4]. Всього розглянуто 6 типів завдань, а саме:

- реконструкція короткої прямої вставки між кривими, спрямованими в один бік;

- реконструкція короткої прямої вставки між кривими, спрямованими в різні боки;

- сполучення складеної кривої перехідними кривими;

- паралельний зсув осі колії на прямій;

- паралельне зміщення осі колії на кривій;

- вирішення складних задач $з$ реконструкції плану лінії методом проекцій.

Основним методом при вирішенні перелічених вище завдань $\epsilon$ :

- визначення геометричних характеристик - кутів, довжин;

- визначення зрушень методом кутових діаграм.

Основним недоліком такого методу вирішення $є$ трудомісткість, крім цього, застосування методу кутових діаграм свідомо вносить відому похибку в результат. Також до недоліків можна віднести те, що розглядалося тільки дві суміжні криві, в той час як на практиці часто трапляються завдання реконструкції дільниці, що містить більше двох кривих.

Слід зазначити також, що в цих завданнях не ставилася безпосередньо мета збільшення радіусів кругових кривих, що стало актуальним нині, коли введення швидкісного руху пасажирських поїздів стало нагальним завданням.

(ㄱ М. Ю. Куценко, О. А. Дудін, Г. В. Пахар, О. М. Даниленко, О. М. Дубина, 2018 
І Н Ф О Р А ЦІЙНО-КЕР У Ю І С ИСТЕ МИ НА З АЛ З НИЧНО М У Т Р АНС ПОРТ І

У [5] міститься опис дев'яти проектних завдань, а також завдання підрахунку зрушень і проектних міжколійїв при проектуванні плану других колій. Тут так само, як і в [6], не ставиться завдання збільшення радіуса кругових кривих. Розглянуто завдання реконструкції стосовно до двох суміжних кривих.

\section{Виділення невирішених раніше частин загальної проблеми}

Загалом, як показав аналіз деяких виконаних проектів реконструкції, проектувальники, як правило, обмежуються перебудовою одиночних кругових кривих, рідко розглядаючи дві, і майже не зачіпають випадки з трьома і більше суміжними кривими.

Метою статті є визначення задач реконструкції плану залізничної колії та підходів щодо їх вирішення.

\section{Основний матеріал статті}

При введенні швидкісного руху основною складністю $є$ реконструкція плану залізничної колії. Ця складність полягає у тому, що суміжні, тобто розташовані близько одна до одної криві з короткими прямими вставками взаємопов'язані. Тому поліпшення характеристик хоча б однієї з кривих тягне зміну, а часто погіршення параметрів інших. Тому такі групи близько розташованих кривих передбачається розглядати як єдине ціле, яке може бути подано у вигляді модуля.

При реконструкції модуля зміни можуть відбуватися тільки усередині нього, не виходячи за його межі. Модулі поєднання кривих, які трапляються на практиці та містять до чотирьох суміжних кривих, можуть бути зображені у вигляді таблиці.

Модуль кривих розглядається у системі прямокутних координат, і тому для кожної з вершин кута $(B K)$ відомі значення $X$ і $Y$.

Реконструкція модуля полягає в тому, щоб знайти такі положення $B K^{n}$, а отже, значення $\left(X^{n} ; Y^{n}\right)$, при яких виконувалися б такі умови:

$S_{i j} \geq S_{i j}^{n}$ та $S_{i j}-S_{i j}^{n} \rightarrow \min$,

де $S_{i j}$-відстань між ВК кривих існуючого плану, м, яка знаходиться як:

$S_{i j}=\sqrt{\left(X_{i}-X_{j}\right)^{2}+\left(Y_{i}-Y_{j}\right)^{2}}$,

де $\left(X_{i} ; Y_{i}\right)$ та $\left(X_{j} ; Y_{j}\right)$ - координати положення відповідних $B K$.

$S_{i j}^{n}$ - проектна відстань між новими положеннями ВК, м, вона знаходиться формулою:

$S_{i j}^{n}=T_{i}+d_{p}+T_{j}$

де $T_{i}, T_{j}$ - тангенси кривих, знайдені при проектному радіусі, м;

$d_{p}$ - проектна пряма вставка, м.

Таблиця

Модулі сполучення кривих, які трапляються на практиці

\begin{tabular}{|l|c|c|c|c|}
\hline \multirow{2}{*}{ Кількість кривих, які входять до блоку } & \multicolumn{4}{|c|}{ Напрямок кута повороту } \\
\cline { 2 - 5 } & 1 & 2 & 3 & 4 \\
\hline \multirow{2}{*}{ Дві криві } & праворуч & праворуч & - & - \\
\hline \multirow{5}{*}{ Три криві } & праворуч & ліворуч & - & - \\
\cline { 2 - 5 } & праворуч & праворуч & праворуч & - \\
\cline { 2 - 5 } & праворуч & ліворуч & праворуч & - \\
\cline { 2 - 5 } & праворуч & праворуч & ліворуч & - \\
\cline { 2 - 5 } & ліворуч & праворуч & праворуч & - \\
\hline \multirow{5}{*}{ Чотири криві } & праворуч & праворуч & праворуч & праворуч \\
\cline { 2 - 5 } & праворуч & праворуч & праворуч & ліворуч \\
\cline { 2 - 5 } & праворуч & праворуч & ліворуч & ліворуч \\
\cline { 2 - 5 } & праворуч & ліворуч & ліворуч & ліворуч \\
\cline { 2 - 5 } & праворуч & ліворуч & праворуч & праворуч \\
\cline { 2 - 5 } & праворуч & праворуч & ліворуч & праворуч \\
\cline { 2 - 5 } & праворуч & ліворуч & праворуч & ліворуч \\
\cline { 2 - 5 } & праворуч & ліворуч & ліворуч & праворуч \\
\hline
\end{tabular}


Підходи, які можуть бути застосовані для вирішення задачі реконструкції модулів, містять:

- виключення або введення однієї або декількох $B K$;

- зміщення однієї або декількох $B K$ по тангенсу;

- зміщення однієї або декількох $B K$ по бісектрисі кутів повороту;

- комбінований підхід, що дає змогу застосовувати спільно окремі елементи перелічених вище пунктів;

- врівноваження величин радіусів суміжних кривих.

Вирішуючи завдання реконструкції модулів, використовуючи ці підходи, можна домогтися збільшення відстані між сусідніми $B K$, а також зменшення значень кутів повороту, що у свою чергу дає можливість поліпшити характеристики плану, тобто збільшити значення радіуса і довжини прямої вставки.

Для визначення відстані між новими положеннями $B K$, як зазначалося вище, потрібно знати кутові коефіцієнти рівнянь прямих, що з'єднують $B K$ існуючого і проектного плану $-K_{i j}$, які знаходяться за формулою:

$K_{i j}=\frac{\left(Y_{i}-Y_{j}\right)}{\left(X_{i}-X_{j}\right)}$

де $\left(X_{i} ; Y_{i}\right),\left(X_{j} ; Y_{j}\right)$ - координати сусідніх $B K$.

Нові координати суміщених $B K$, м:

$X_{i}^{n}=X_{i}-d_{i} \cdot \cos \left(\operatorname{arctg} K_{i j}\right)$,

$Y_{i}^{n}=Y_{i}-d_{i} \cdot \sin \left(\operatorname{arctg} K_{i j}\right)$,

де $\left(X_{i}^{n} ; Y_{i}^{n}\right)$ - координати нового положення $B K_{i}$;

$\left(X_{i} ; Y_{i}\right)$ - координати існуючої $B K_{i}$;

$d_{i}$ - величина суміщення положення $B K_{i}$ по тангенсу, м.

При зміні положення $B K$ також змінюються кути повороту, град, величини яких знаходяться таким чином:

$\alpha_{n}=\operatorname{arctg}\left(\frac{K_{i j}^{n}-K_{k i}}{1+K_{i j}^{n} \cdot K_{k i}}\right)$,

де $\alpha_{n}-$ значення нового кута повороту, град;

$K_{i j}^{n}$ - кутовий коефіцієнт проектної прямої між $B K$;

$K_{k i}$ - кутовий коефіцієнт існуючої прямої між $B K$.
Зсув осі колії, який при такій реконструкції траси досягає величин кількох десятків метрів, не завжди може слугувати вирішальним критерієм для оцінки варіанта рішення.

Однак, якщо виникає така необхідність, то використання часто застосовуваного методу кутових діаграм для підрахунку величин зміщення після реконструкції не завжди доцільне, оскільки це призводить до істотних похибок, які спотворюють загальну картину. Похибки викликані зміною не тільки значень кутів повороту, а й довжини ділянки траси, що входить у модуль.

Застосування такого підходу, як зміщення $B K$, може бути обмежене, оскільки, займаючи нове положення, траса лінії, можливо, перетне прилеглу будівлю, яка не підлягає знесенню.

Тоді необхідно обмежити величини зміщення $B K$ модуля. Це обмеження вводиться умовою, що відстань $(S)$ від проектного положення траси до критичної точки $(P)$ має відповідати габариту наближення будови на швидкісних лініях (рисунок). Для цього подаємо пряму лінію, що сполучає дві зміщені $B V$, у вигляді рівняння

$\left|\begin{array}{lll}X & Y & 1 \\ X_{1}^{n} & Y_{1}^{n} & 1 \\ X_{2} & Y_{2} & 1\end{array}\right|=0$

Рівнянню (8) можна надати вигляду

$A x+B y+C=0$,

де $A, B, C$ - коефіцієнти, які відповідно дорівнюють

$A=\left|\begin{array}{ll}Y_{1}^{n} & 1 \\ Y_{2} & 1\end{array}\right| ; \quad B=-\left|\begin{array}{cc}X_{1}^{n} & 1 \\ X_{2} & 1\end{array}\right| ; \quad C=\left|\begin{array}{ll}X_{1}^{n} & Y_{1}^{n} \\ X_{2} & Y_{2}\end{array}\right|$,

тоді відстань від нової проектної прямої до критичної точки знаходиться як, м,

$S=\left|\frac{A \cdot x_{p}+B \cdot y_{p}+C}{\sqrt{A^{2}+B^{2}}}\right|$.

Отже, якщо $S$ дорівнює габариту наближення будови, то зміщення ВК (у даному випадку BK1) слід припинити. 


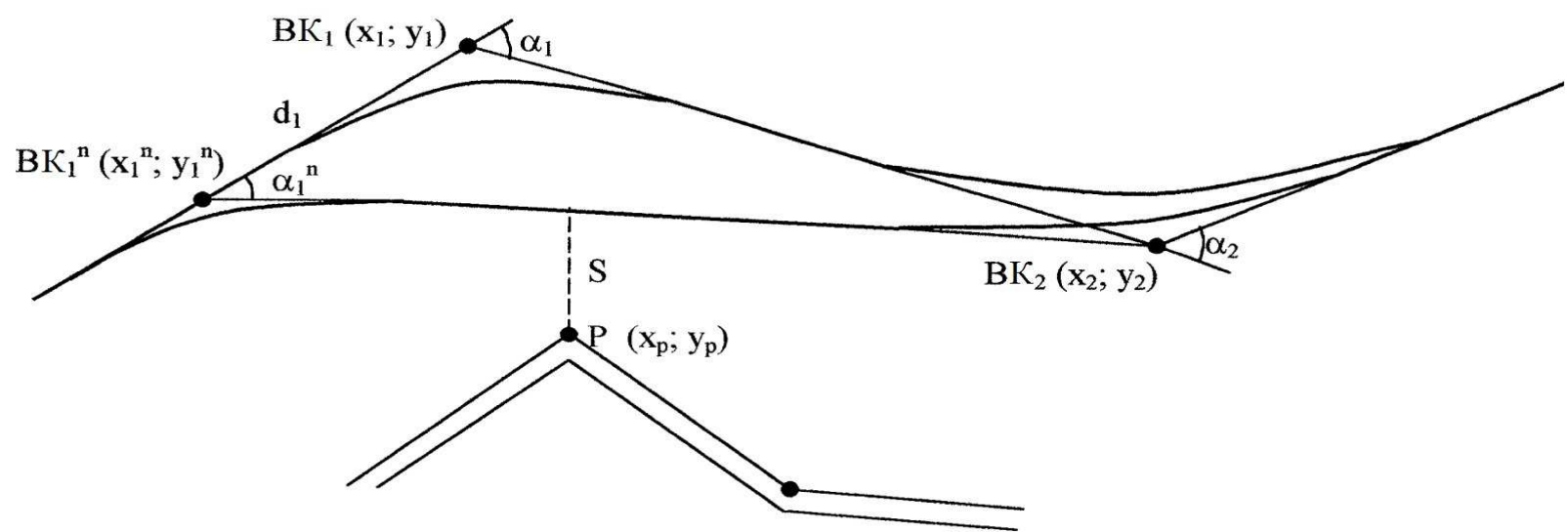

Рис. Визначення обмеження суміщення $B K$ по контуру

\begin{abstract}
Висновок
У результаті застосування різних підходів до вирішення завдання реконструкції модуля можна отримати кілька варіантів. Оцінка і порівняння цих варіантів залежно від умов і необхідного рішення, а також вимог, що висуваються до дільниці реконструкції, можуть здійснюватися за такими критеріями:

- найменша довжина реконструкції;

- зручність реалізації варіанта реконструкції;

- найменше зайняття території;

- приведені витрати, які включають вартість реконструкції і експлуатаційні витрати.

Найбільш загальним рішенням був би багатокритеріальний підхід, для чого слід дати вагові коефіцієнти деяким із зазначених критеріїв.

Загальними для всіх варіантів реконструкції $\epsilon$ критерії: мінімальна довжина реконструкції та приведені витрати, оскільки інші запропоновані критерії мають індивідуальний характер, незважаючи на це вирішальним може виявитися кожен з них.

Після прийняття рішення 3 реконструкції можна очікувати, що при існуючих зсувах траси в плані можливим буде вихід за межі смуги відведення, знесення споруд і заняття культивованих земель. Крім цього, капітальні витрати, вкладені в реконструкцію складних модулів, можуть бути істотними, які в ряді випадків, можливо, окупляться за рахунок економії в експлуатаційних витратах. Така економія може виникнути через зняття обмеження швидкості руху поїздів.
\end{abstract}

\section{Список використаних джерел}

1. Аналіз досліджень, присвячених реконструкції проміжних роздільних пунктів при введенні швидкісного руху [Текст] / М. Ю. Куценко, О. А. Дудін, А. В. Рибін [та ін.] // Зб. наук. праць Укр. держ. Ун-ту залізнич. трансп. - Харків : УкрдУЗТ, 2016. - Вип. 165. - С. 109-117.
2. Визначення структури будівельних робіт 3 реконструкції роздільних пунктів при введенні швидкісного руху [Текст] / М. Ю. Куценко, Г. В. Шаповал, А. М. Івашкіна, Я. А. Шкарбуль // Зб. наук. праць Укр. держ. ун-ту залізнич. трансп. - Харків : УкрДУЗТ, 2017. - Вип. 173. - С. 29-35.

3. Турбин, И. В. Изыскания и проектирование железных дорог [Текст] : учебник // И. В. Турбин, А. В. Гавриленков, И. И. Кантор. - М. : Транспорт, 1989. - 479 c.

4. Проектирование вторых путей: справочное и методическое руководство [Текст] / под общ. ред. Г. З. Верцмана и А. П. Володина. - М. : Транспорт, 1970. -359 c.

5. Методические указания по использованию проектирующих программ плана вторых путей [Текст]. - М. : Мосгипротранс, 1985. - Ч. II. - 61 с.

6. Проектирование, строительство и реконструкция железных дорог [Текст] // В. А. Бучкин, Ю. А. Быков, В. А. Копыленко, . В. Яковлев. - М. : Транспорт, 1989. - 263 с.

7. High-speed railway scheduling based on user preferences [Text] / J. Espinosa-Aranda [et al.] // European Journal of Operational Research. - 2015, November. - Vol. 246. - P. 772 - 786.

8. Environmental risks of high-speed railway in China: Public participation, perception and trust [Text] / Guizhen He [et al.] // Environmental Development. 2015, April. - Vol. 14. - P. 37 - 52.

9. Clewlow, R. R. The impact of high-speed rail and low-cost carriers on European air passenger traffic [Text] / R. R. Clewlow, J. M. Sussman, H. Balakrishnan // Transport Policy. - 2014. Vol. 33. - P. 136 - 143. 


\begin{abstract}
Куценко М. Ю., Дудин А. А., Пахар Г. В., Даниленко Е.Н., Дубина А. М. Задачи реконструкции плана железнодорожного пути и подходы к их решению. Процесс прехода к скоростному движению сопровождается с рядом проблем, главными из которых являются задачи переустройства плана железных дорог. В статье рассмотрены основные задачи по реконструкции плана железнодорожного пути и подходы к их решению. Предложено рассматривать реконструкцию сложных участков плана для ввода скоростного движения как задачи улучшения параметров модулей, из которых состоит этот план. Реконструкцию следует осуществлять внутри модуля, не выходя за его пределы, что позволит сохранить существующее положение плана.
\end{abstract}

Ключевые слова: железнодорожный транспорт, железная дорога, скоростное движение, реконструкция железных дорог.

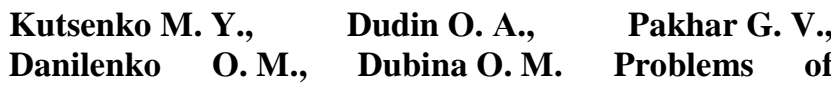
reconstruction of the railway track plan and approaches to their solution. In the past decades, highspeed passenger traffic has been introduced all over the world on operating railways, it was driven by the imperatives of our era as a means of surviving railways in competition with other modes of transport, primarily aviation.

With the introduction of high-speed traffic, the main difficulty is the reconstruction of the railway track plan. This difficulty lies in the fact that the adjacent, that is, located close to each other curves with short straight inserts are interconnected. Therefore, an improvement in the characteristics of at least one of the curves entails a change, and often a deterioration in the parameters of others. Therefore, such groups of closely spaced curves are supposed to be considered as a whole, which can be represented as a module.

It has been proposed to consider the reconstruction of complex sections of the plan for entering high-speed traffic, as the task of improving the parameters of the modules that make up this plan. The reconstruction should be carried out inside the module, without going beyond its limits, which will preserve the existing position of the plan. It has been concluded that the following criteria are common for all reconstruction options: minimum reconstruction length and reduced costs.

Key words: railway transport, railway, high-speed traffic, reconstruction of railways.
Куценко Максим Юрійович, кандидат технічних наук, дочент кафедри залізничних станцій та вузлів, Украӥнський державний університет залізничного транспорту, Харків, України. E-mail: maksimus84@meta.ua. http://orcid.org/0000-0001-60207749.

Дудін Олексій Аркадійович, кандидат технічних наук, дочент кафедри коліі та колійного господарства, Украӥнський державний університет залізничного транспорту, Харків, України. E-mail: aadudin@ukr.net. http://orcid.org/0000-0002-6838-1669.

Пахар Галина Василівна, магістр кафедри залізничних станцій та вузлів, Український державний університет залізничного транспорту, Харків, України. E-mail: pakhar92@ukr.net.

Даниленко Олена Миколаӥвна, магістр кафедри залізничних станиій та вузлів, Український державний університет залізничного транспорту, Харків, України. E-mail: o.danilenko@meta.ua.

Дубина Олександр Михайлович, магістр кафедри залізничних станиій та вузлів, Український державний університет залізничного транспорту, Харків, України. E-mail: o.m.dubina@gogle.com.

Maksym Kutsenko, candidate of technical sciences, associate professor of railroad stations and junctions department, Ukrainian State University of Railway Transport, Kharkiv, Ukraine. E-mail: maksimus84@meta.ua. http://orcid.org/0000-0001-60207749.

Olexii Dudin, candidate of technical sciences, associate professor of track and track facilities department, Ukrainian State University of Railway Transport, Kharkiv, Ukraine. E-mail: aadudin@ukr.net. http://orcid.org/00000001-6020-7749.

Galina Pakhar, master railroad stations and junctions department, Ukrainian State University of Railway Transport, Kharkiv, Ukraine. E-mail: : pakhar92@ukr.net. Olena Danilenko, master railroad stations and junctions department, Ukrainian State University of Railway Transport, Kharkiv, Ukraine. E-mail: o.danilenko@meta.ua.

Olexander Dubina, master railroad stations and junctions department, Ukrainian State University of Railway Transport, Kharkiv, Ukraine. E-mail: o.m.dubina@gogle.com. 